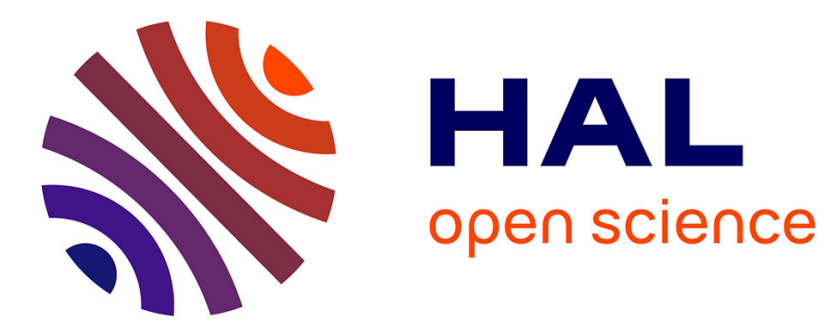

\title{
Electromagnetic Properties of Mn-Zn Ferrite
}

T. Nakamura, Y. Okano

\section{To cite this version:}

T. Nakamura, Y. Okano. Electromagnetic Properties of Mn-Zn Ferrite. Journal de Physique IV Proceedings, 1997, 07 (C1), pp.C1-101-C1-102. 10.1051/jp4:1997129 . jpa-00255006

\section{HAL Id: jpa-00255006 https://hal.science/jpa-00255006}

Submitted on 1 Jan 1997

HAL is a multi-disciplinary open access archive for the deposit and dissemination of scientific research documents, whether they are published or not. The documents may come from teaching and research institutions in France or abroad, or from public or private research centers.
L'archive ouverte pluridisciplinaire HAL, est destinée au dépôt et à la diffusion de documents scientifiques de niveau recherche, publiés ou non, émanant des établissements d'enseignement et de recherche français ou étrangers, des laboratoires publics ou privés. 


\title{
Electromagnetic Properties of Mn-Zn Ferrite
}

\author{
T. Nakamura and Y. Okano
}

R\&D Division, Toda Kogyo Corporation, 4-1-2 Funairi-minami, Naka-ku, Hiroshima 730, Japan

\begin{abstract}
Mn-Zn fertite ceramics were prepared through usual ceramic method using different iron oxide raw matcrials. The micro-structure parameters, stch as the sintering density and the ferrite grain size, depended on both the sintering temperature and the kinds of iron oxide raw materials. The differences in the microstructure parameters were responsible for rariations in magnetization, permeability, electrical resistivity and power loss. Additionally, it was claritied that the relationship betiven micro-structural and electromagnetic properties were uniquely explained using the non-magnetic and insulating grain boundary model, irrespective of the kinds of iron oxide raw materials.
\end{abstract}

\section{INTRODUCTION}

Polycrystalline Mn-Zn ferrites have been used widely in high frequency devices such as transformers and magnetic heads. Recently, the dimension of the electronic devices has been reduced. and simultaneously. the driving frequency of switching power supplies has been raised to the $1 \mathrm{MHz}$ range. in which the power loss drastically increases[1.2]. The suppression of the power loss is an important problem in the case that the ferrite is utilized for high-frequency devices.

It is thought that the electromagnetic properties of $\mathrm{Mn}-\mathrm{Zn}$ ferrite are sensitive to the micro-structure. since they are in polycrystalline form. Hence, investigation about the effect of starting materials on the micromstructurc in the polycrystalline ferrite provides useful information on the control of the electromagnetic properties. In this study. we lave studied the effect of iron oxide raw materials, and have discussed the relationship between the ceramics micro-structural and clectromagnetic properties.

\section{EXPERIMENTS}

$\mathrm{Mn}-\mathrm{Zn}$ ferrite sintered ceramics were prepared by usual ceramic method. The starting particles of $\alpha_{2}-\mathrm{Fe}_{2} \mathrm{O}_{3} \cdot \mathrm{MnCO}_{3}$ and $\mathrm{ZnO}$ were mixed together through wet attrition milling, with the cation ratio adjusted to $\mathrm{Mn}_{0.73} \mathrm{Zn}_{0.20} \mathrm{Fe}_{2.07} \mathrm{O}_{4}$. Two types of $\alpha-\mathrm{Fe}_{2} \mathrm{O}_{3}$ particles were utilized. Powder $\mathrm{C}$ was synthesized by calcination of $\mathrm{FeCl}_{3} \mathrm{nH}_{2} \mathrm{O}$ salts at $800{ }^{\circ} \mathrm{C}$ in air and then by dry vibration milling. Powder $\mathrm{S}$ was obtained by the oxidation of $\mathrm{Fe}_{3} \mathrm{O}_{4}$ particles. precipitated by acrial oxidation of alkaline $\mathrm{FeSO}_{4} 7 \mathrm{H}_{2} \mathrm{O}-\mathrm{NaOH}$ suspension, at $800^{\circ} \mathrm{C}$ in air and then by dry vibration. The mixed powders were then calcined in air at $860^{\circ} \mathrm{C}$ for six hours and slowly cooled to room temperature. They were re-ground under $80 \mu \mathrm{m}$ through wet bail milling. In the milling process. $\mathrm{CaO}$ and $\mathrm{SiO}_{2}$ were introduced as the constitution components in the insulating layer. the tolal amount of which were adjusted to 200 and $100 \mathrm{ppm}$, respectively. The obtained powders were then mixed with an appropriate amount of poly-vinyl-alcohol (as a binder). subjected to press compacting (disc with the diameter of $50 \mathrm{~mm}$ and the thickness of about $5 \mathrm{~mm}$ ), and then sintered in static air at temperature ranging from $1250^{\circ} \mathrm{C}$ to $1325^{\circ} \mathrm{C}$ for six hours and slowly cooled to room temperature in an $\mathrm{N}_{2}$ atmosphere.

\section{RESULTS AND DISCUSSION}

The average particle size of powder $\mathrm{C}(0.19 \mu \mathrm{m})$ was slightly smaller than that of powder $\mathrm{S}(0.25 \mu \mathrm{m})$. In addition. powder $\mathrm{C}$ had a large amount of $\mathrm{Cl}$ impurity $(0.11 \mathrm{wt} \%)$ and powder $\mathrm{S}$ had large amounts of $\mathrm{Na}(150 \mathrm{ppm})$ and $\mathrm{SO}_{4}(0.3+\mathrm{w} t \%)$. which 
were attributed to the Fe source materials and to the preparation methods. Sintering density. average size of ferrite grain. magnetization, permeability and electrical resistivity are listed in Table 1. It was found that all of them increased with the sintering temperature. and also that using powder $S$ yielded greater values at the same sintering temperature. It is known that both the magnetization and the permeability increase with the volume loading of the ferrite and with the magnetic connection between the ferrite grains, and that the electrical conduction is enhanced by the electrical percolation and by the inter-grain connection. Therefore. these results indicate the advantage of using powder $S$ as the raw materials : easy sintering at lower temperature. Power loss of each sintered specimen was then measured in the frequency range from $1 \mathrm{kH} /$ to $1 \mathrm{MHz}$ at the excitation magnetic flux density less than $200 \mathrm{mT}$. Considering the frequency dependence. the power loss was separated into hysteresis and eddy current components. It was found that the hysteresis loss decreases and the eddy current loss increases with increase of the sintering temperature. and that using powder S provided greater eddy current loss and lower hysteresis loss than using powder $\mathrm{C}$ at the same sintering temperature. Generally speaking. the hysteresis loss is inversely proportional to permeability and the eddy current loss increases with decrease in the electrical resistivity. Therefore. the specimen with greater permeability have lower hysteresis loss and those with high resistivity have lower eddy current loss. The experimental results of power loss can be explained along this consideration. Since the power loss in higher frequency region is mainly attributed to the eddy current loss, using powder $\mathrm{C}$ as iron oxide raw materials is thought to be suitable for the reduction of power loss in high-frequency region. Consequently, it was clear that using powder $S$ as iron oxide raw material provides lower-temperature sintering but causes the enhancement of the power loss in high frequency region.

Table 1: Micro-structural and electromagnetic properties of the sintered ferrite

\begin{tabular}{|c|c|c|c|c|c|c|}
\hline Raw material & Sintering temp. $\left({ }^{\circ} \mathrm{C}\right)$ & Density $(g / c 0)$ & Grain size ( $(\mu \mathrm{m})$ & Magnetization $(\mathrm{G})$ & Permeability & Resistivity ( $(2 \mathrm{~cm})$ \\
\hline powder C & 1275 & 4.89 & 10 & 4740 & 1450 & $1.54 \times\left[0^{5}\right.$ \\
\hline powder $\mathrm{C}$ & 1325 & 4.93 & 14 & 4960 & 2200 & $1.03 \times 10^{5}$ \\
\hline powder $s$ & 1275 & 4.91 & 12 & 4800 & 1500 & $1.11 \times 10^{5}$ \\
\hline powder $S$ & 1.325 & 4.96 & 18 & 5140 & 2500 & $0.89 \times 10^{5}$ \\
\hline
\end{tabular}

Further, we have examined the relationship between the micro-structural and the electromagnetic properties of $\mathrm{Mn}-\mathrm{Zn}$ ferrite sintered ceramics. It was found that magnetization. permeability and conductivity increased with increases in sintering density and grain size. irrespective of the kinds of iron oxide raw materials. In other word. the variation of the electromagnetic property versus the sintering density or the ferrite grain size can be described by a single line. This allows us to evaluate the variations of the electromagnetic property as a unique function of microstructural parameter. These variations can be qualitatively explained using the non-magnetic and insulating grain boundary layer model : magnetic and conductive ferrite grains are surrounded by a non-magnetic insulating inter-grain layer[3-5]. Although. in general, the ferrite grain size and the grain boundary layer thickness have certain distributions. we use their average values. According to this model. the micro-structural parameter is represented as the ratio of the grain size to the boundary thickness. and the sintering density increases with this ratio. Additionally. the electromagnetic properties of the polycrystalline ferrite. such as magnetization. permeability and electrical resistivity. are determined uniquely by the ratio of the grain size to the boundary thickness. These are qualitatively in congruence with the experimental results. From the above considerations, although the micro-structure of the sintered ferrite depends on the kinds of iron oxide raw materials, the microstructural differences can be restored by selecting appropriate sintering temperature. As a result. different microstructural properties in the sintered ferrite produces different electromagnetic properties. and the differences in electromagnetic properties can also be restored by selecting appropriate sintering conditions. Hence, using powder $S$ as iron oxide naw materials has great advantage in industrial production. that is. sintered ceramics can be obtained at lower temperature.

\section{CONCLUSIONS}

The micro-structure of the sintered ferrite depends on both the sintering temperature and the kinds of iron oxide raw materials, and the microstructural differences affect their microstnuctural properties. The differences originated from the kinds of iron oxide raw materials can be restored by selecting appropriate sintering conditions. Therefore, using powder with easy sintering ability has great advantage in industrial production.

\section{References}

[1] J. Smit and H.P.J. Wijn, Ferrites (Phillips Technical Library, Eindhoven. The Netherlands. 1959). p. 134.

[2] T. Sato and Y. Sakaki. IEEE Trans. Magn. 26.2894 (1990).

[3] M.T. Johnson and E.C. Visser, IEEE Trans. Magn. 26, 1987 (1990).

[4] P.J. van der Zaag. J.J.M. Ruigrok, A. Noordermeer, M.H.W.M. van Delden, P.T. Por, M. Th. Rekveldt. D.M. Donnet. and J.N. Chapman, J. Appl. Phys. 74, 4085 (1993).

[5] T. Nakamura. T. Tsutaoka and K. Hatakeyama, J. Magn. Magn, Mater. 138, 319 (1994). 